\title{
PENGARUH KINERJA KEUANGAN TERHADAP NILAI PERUSAHAAN MANUFAKTUR DI BURSA EFEK INDONESIA DENGAN KEBIJAKAN DIVIDEN SEBAGAI VARIABEL MODERASI
}

\author{
Riska $^{1}$, Hendra Raza ${ }^{2 *}$, Andria Zulfa ${ }^{3}$ \\ ${ }^{123}$ Pascasarjana Ilmu Manajemen, Universitas Malikussaleh Lhokseumawe \\ Email:riska.95144@gmail.com¹, hendraraza@unimal.ac.id², andriazulfa@unimal.ac.id ${ }^{3}$
}

\begin{abstract}
This study aims to examine the effect of profitability, liquidity and leverage on firm value with dividend policy as a moderating variable on Manufacturing Companies on the Stock Exchange during the 2014-2018 period. The number of samples in this study are 28 Manufacturing Companies on the Stock Exchange that provide regular dividends during the 2014-2018 period. The type of data used is secondary data in the form of panel data obtained from the company's Annual Report. Data analysis method used is Panel Data Regression. The results of this study found that profitability, leverage and dividend policy had a positive and significant effect on firm value, but liquidity had no significant effect on firm value. The moderating effect proves that the dividend policy is able to moderate the effect of profitability, liquidity and leverage on the value of the company, where the dividend policy belongs to the type of variable Quacy Moderator.

Keywords : $\quad$ Profitability, Liquidity, Leverage, Dividend Policy and Company Value
\end{abstract}

\section{PENDAHULUAN}

Perkembangan pasar modal sangat Nilai perusahaan merupakan aspek yang sangat penting karena hal tersebut mampu mencerminkan kinerja perusahaan yang dapat mempengaruhi persepsi investor terhadap perusahaan. Halimah \& Komariah (2017) berpendapat bahwa nilai perusahaan menjadi indikator yang tepat untuk melihat seberapa besar kekayaan pemegang saham dalam perusahaan tersebut. Nilai perusahaan yang tinggi menggambarkan bahwa kinerja perusahaan dalam keadaan baik sehingga dapat meyakinkan investor akan baiknya prospek perusahaan dimasa mendatang.

Nilai perusahaan dapat diketahui dengan beberapa rasio, seperti rasio PBV, PER, Return saham, MBVA dan Tobins Q (Anto, 2016; Apsari et al., 2015; Cahyono, 2016; Dewi \& Suaryana, 2013; Darmawati et al., 2018). Akan tetapi, penelitian ini menggunakan teori Tobins Q, dimana tobins Q adalah nilai pasar commom stock dan financial liabilities. Yang merupakan perbandingan nilai pasar perusahaan dengan nilai investasi bersihnya jika harga saham meningkat maka nilai pasar perusahaan juga akan mengalami peningkatan. Dengan kata lain, Tobins Q merupakan gambaran statistik yang berfungsi sebagai proksi dari nilai perusahaan.

Riset sebelumnya juga menemukan bahwa nilai Tobins Q di Indonesia untuk periode selama periode 2009-2013 sebesar 1,13 dan menurun menjadi 1,01 untuk periode 2003-2013 (Nikolaus, 2015; Darmawati et al., 2018). Nilai tersebut tergolong masih berada dalam kondisi yang baik dikarenakan berada di atas angka 1. Untuk nilai perusahaan di sektor manufaktur di Indonesia, nilai rata-rata Tobins Q pada sektor manufaktur yang hanya sebesar 1,92 untuk periode 2007-2015 dan menurun menjadi 1,89 untuk periode 2010-2016 (Indrawan, 2015; Kurnia, 2017). Nilai tersebut berada di atas satu yang menunjukkan bahwa nilai perusahaan sektor manufaktur berada pada kondisi 
overvalue. Nilai Tobins Q dari tahun 2014-2018 mengalami fluktuasi dan nilainya juga berada di atas rata-rata 1 setiap tahunnya, sehingga dapat disimpulkan bahwa nilai perusahaan sektor manufaktur tergolong bagus. Menurut Fauziah (2017), Tobin's Q di atas 1 menujukkan bahwa saham dalam kondisi over value. Artinya manajemen berhasil dalam mengelola aktivas perusahaan dan memiliki potensi pertumbuhan investasi yang tinggi, akan tetapi kinerja perusahaan yang diukur dengan ROA, CR dari tahun 2014 s/d 2018 mengalami fluktuasi akan tetapi sebagai pedoman umum tingkat Current Ratio 2.00 sudah dianggap baik (Kasmir, 2014). yang menunjukkan bahwa kemampuan perusahaan manufaktur dalam melunasi kewajiban jangka pendeknya terbilang baik. Diikuti dengan nilai DAR dan nilai kebijakan dividen (DPR) yang juga mengalami fluktuasi dari waktu ke waktu. Dapat dikaitkan dengan teori bahwa kinerja keuangan sangat mempengaruhi nilai perusahaan.

Hasil rekapitulasi data tersebut juga sejalan dengan ungkapan Tjandrakirana \& Monika (2019) yang menemukan bahwa di tahun 2018 industri manufaktur sedang mengalami peningkatan dengan kapitalisasi pasar sebesar Rp 401,18 triliun, naik 28,18\% dibandingkan saat menutup 2017 dengan nilai kapitalisasi pasar Rp 312,98 triliun. Pertumbuhan kapitalisasi pasar perusahaan manufaktur year on year (yoy) tersebut jauh melampaui rata-rata Indeks Harga Saham Gabungan (IHSG) yang pada periode tersebut tumbuh 15,3\%. Hal tersebut menunjukkan bahwa sektor manufaktur memberikan kontribusi yang dominan dalam meningkatkan IHSG dan mengindikasikan bahwa perusahaan sektor manufaktur menjadi sektor dengan nilai perusahaan yang baik, sehingga menarik untuk dikaji.

Berdasarkan permasalahan dan research gap di atas, maka penulis tertarik untuk melakukan suatu kajian empiris mengenai "Pengaruh Kinerja Keuangan terhadap Nilai Perusahaan Manufaktur di Bursa Efek Indonesia dengan Kebijakan Dividen sebagai Variabel Moderasi”.

\section{LITERATUR REVIEW DAN HIPOTESTS}

\section{Pengaruh Profitabilitas Terhadap Nilai Perusahaan}

Profitabilitas memperlihatkan sejauh mana perusahaan mengelola modal sendiri secara efektif, mengukur tingkat keuntungan dari investasi yang telah dilakukan oleh pemilik modal sendiri atau pemegang saham. Profitabilitas dalam penelitian ini diwakili oleh Return On Assets merupakan salah satu rasio yang mengukur kemampuan perusahaan menghasilkan laba bersih berdasarkan tingkat asset yang tertentu (Horne dan Wachiwicz, 2005).

Profitabilitas merupakan rasio yang menunjukkan pengelolaan perusahaan dalam mencapai peningkatan laba (Aspari et al., 2015). Perusahaan dengan proftibailitas yang tinggi akan mendorong peningkatan nilai perusahaannya dikarenakan dapat memberikan keuntungan bagi pemegang kepentingan perusahaan (Patricia et al., 2018). Hal ini menunjukkan bahwa profitabilitas menjadi aspek penting yang berikaitan dengan nilai perusahaan.

Profitabilitas dapat dihitung dengan Return on Asset yang merupakan perbandingan laba bersih dengan aset perusahaan yang dapat diformulasikan sebagai berikut (Zeitun \& Saleh, 2015; Darmawati 
et al., 2018). Tinggnya profitabilitas akan memberikan sinyal ke pasar modal bahwa kondisi kinerja perusahaan berada pada posisi yang bagus sehingga menarik minat calon investor di pasar modal. Ross (1977) juga berpendapat bahwa profitabilitas dapat memancarkan sinyal positif ke pasar modal sehingga meningkatkan nilai perusahaan. Beberapa riset sebelumnya juga menunjukkan bahwa profitabilitas berpengaruh positif terhadap nilai perusahaan (Ihsan \& Sanjani, 2015; Patricia et al., 2018; Le, 2019).

\section{Pengaruh Pengaruh Likuiditas Terhadap Nilai Perusahaan}

Likuiditas menggambarkan kemampuan suatu perusahaan untuk memenuhi kewajiban finansialnya yang segera harus dipenuhi. Likuiditas dalam penelitian ini diwakili oleh Current Ratio merupakan salah satu rasio yang paling umum digunakan untuk mengukur likuiditas atau kemampuan perusahaan untuk memenuhi kewajiban jangka pendek tanpa menghadapi kesulitan. Likuiditas merupakan kemampuan perusahaan dalam memenuhi kewajibannya (Zuhroh, 2019). Semakin tinggi likuiditas menunjukkan bahwa kemampuan perusahaan dalam memenuhi kewajibannya sekain tinggi dan kinerja perusahaan menjadi semakin baik (Hidayat et a., 2019). Likuiditas dapat meningkatkan nilai perusahaan dengan adanya penurunan biaya pengeluaran modal, sehingga kebijakan investasi meningkat dan kepercayaan investor juga ikut meningkat (Cheung et al. 2015).

Likuiditas menjadi aspek yang dapat meningkatkan kepercayaan invesort (Faure-Grimaud, A., \& Gromb, 2004). Likuiditas yang tinggi mengindikasikan bahwa perusahaan berada pada kondisi yang baik sehingga permintaan saham perusahaan meningkat dan nilai perusahaannya meningkat (Mentalitas, 2018). Uraian tersebut menunjukkan bahwa likuditas berpengaruh positif dan signifikan terhadap nilai perusahaan, artinya semakin tinggi likuiditas perusahaan, maka nilai perusahaannya semakin meningkat. Hal ini juga dibuktikan oleh beberapa studi sebelumnya yang menemukan bahwa likuiditas memberikan efek positif dan signifikan terhadap nilai perusahaan (Lubis et al., 2013; Rudianto, 2019; Cheung et al. 2015).

\section{Pengaruh Leverage Terhadap Nilai Perusahaan}

Leverage adalah mengukur kemampuan perusahaan untuk memenuhi kewajiban finansialnya yang terdiri dari utang jangka pendek dan utang jangka panjangnya. Leverage didalam penelitian ini diwakili oleh Debt to Assets Ratio merupakan rasio utang yang digunakan untuk mengukur perbandingan antara total utang dengan total aktiva. Dengan kata lain, seberapa besar aktiva perusahaan berpengaruh terhadap pengelolaan aktiva. (Kasmir, 2014). Tingginya leverage pada suatu perusahaan mengindikasikan bahwa perusahaan tersebut memiliki sumber pendanaan eksternal yang tinggi. Berdasarkan MM Theory (MM, 1963) yang menyatakan bahwa tingkat hutang dapat meningkatkan nilai perusahaan dengan memperoleh keuntungan dari pajak. Di sisi lain, trade off theory yang dikemukakan oleh Myers (1984) menyatakan bahwa hutang menjadi alat yang dapat meningkatkan nilai perusahaan dengan selama biaya keuntungannya lebih besar dibandingkan biaya 
kesulitan keuangan. Argumentasi dan teori di atas menunjukkan bahwa struktur modal berpengaruh positif dan signifikan terhadap nilai perusahaan. Beberapa hasil penelitian sebelumnya menemukan bahwa leverage berpengaruh positif dan signifikan terhadap nilai perusahaan yang artinya tingginya leverage akan membuat nilai perusahaan meningkat (Ruzita et al., 2010; Darmawati et al., 2018; Muharti \& Anita, 2017).

\section{Pengaruh Kebijakan Dividen Terhadap Nilai Perusahaan}

Dividen merupakan keuntungan yang diperoleh pemegang saham. Kebijakan dividen dapat diukur dengan ratio Dividend Payout Ratio (DPR) yang merupakan perbandingan antara dividen per lembar saham terhadap laba per lembar saham (Roy, 2015; Natalia \& Kusumastuti, 2017). Kebijakan dividen menentukan berapa banyak laba yang harus dibagikan kepada pemegang saham dan laba yang harus digunakan kembali sebagai modal operasional perusahaan (Kholis et al., 2014). Dilihat dari sisi pemegang saham, perusahaan yang mampu membayar dividen akan menarik investor-investor di pasar modal untuk berinvestasi dan menciptakan nilai perusahaan yang tinggi (Dewi \& Wirasadena, 2018).

Investor akan menyukai perusahaan dengan tingkat pemberian dividen yang tinggi dari pada mengaharapkan capital gain, karena berdasarkan Bird in The Hand Theory, dividen memiliki risiko yang kecil dan dapat dikontrol. Hal ini tentunya akan memancarkan sinyal ke investor sehingga nilai perusahaan meningkat. Kebijakan dividen dapat diukur dengan rasio dividen per lembar saham terhadap laba per lembar saham (Ihsan \& Sanjani, 2015; Anton, 2016). Hasil penelitian sebelumnya menemukan bahwa dividen berpengaruh positif terhadap nilai perusahaan yang artinya tingginya dividen yang diberikan akan meningkatkan nilai perusahaan di pasar modal (Ihsan \& Sanjani, 2015; Dewi \& Wirasadena, 2018; Darmawati et al., 2018).

\section{Kebijakan Dividen Memoderasi Pengaruh Profitabilitas Terhadap Nilai Perusahaan}

Manajer dalam perusahaan memiliki perhatian terhadap cash holding yang ada dalam perusahaan dan menginvestasikannya pada proyek yang pengembaliannya bertujuan hanya meningkatkan gengsi pribadi tanpa memperhatikan kepentingan para pemegang sahan (Jensen, 1986). Pemberian dividen akan berdampak terhadap kekurangan dana untuk diinvestasikan, sehingga menuntut perusahaan untuk mengambil dana eksternal (Giriati, 2016). Dengan demikian, adanya peranan kebijakan dividen membuat investasi berkurang sehingga nilai perusahaan akan menurun. Maka dari itu, kebijakan dividen mampu memperburuk hubungan investasi dan nilai perusahaan (Cheng \& Zheng, 2011; Khairani \& Agustina, 2018).

\section{Kebijakan Dividen Memoderasi Pengaruh Likuiditas Terhadap Nilai Perusahaan}

Likuiditas yang diproksikan dengan current ratio merupakan kemampuan aset perusahaan dalam melunasi kewajiban jangka pendeknya (Mentalitas, 2018). Perusahaan dengan likuiditas yang tinggi mengindikasikan bahwa perusahaan memiliki arus kas yang lebih dalam melunasi 
kewajibannya sehingga berdampak pada kebijakan dividen dan nilai perusahaan (Sukini, 2012). Ketika perusahaan memutuskan untuk membayar dividen, maka arus kas bebas pada perusahaan tersebut berkurang, sehingga kemampuan perusahaan dalam melunasi kewajibannya berkurang, dan hal tersebut memberikan sinyal kepada pasar (Jensen, 1986). Uraian tersebut menunjukkan bahwa kebijakan dividen memoderasi pengaruh likuiditas terhadap nilai perusahaan. Hal tersebut juga telah dibuktikan oleh riset-riset sebelumnya yang telah membuktikan bahwa kebijakan dividen mampu memoderasi pengaruh likuiditas terhadap nilai perusahaan (Pascareno \& Siringoringo, 2016; Mentalita, 2019).

\section{Kebijakan Dividen Memoderasi Pengaruh Leverage Terhadap Nilai Perusahaan}

Salah satu cara bagi perusahaan untuk mendapatkan tambahan modal adalah dengan meminjam dana dari pihak luar. Pemenuhan modal yang berasal dari sumber dana eksternal akan menentukan kemampuan perusahaan dalam melakukan aktivitasnya sekaligus meningkatkan risiko keuangan perusahaan tersebut (Cheng \& Zheng, 2011). Dalam komposisi tertentu, utang akan meningkatkan produktivitas perusahaan sehingga meningkatkan kemampuan perusahaan dalam menghasilkan laba bagi pemegang saham. Kebijakan dividen merupakan bagian yang menyatu dengan keputusan pendanaan yang menyangkut pembelanjaan internal perusahaan sehingga dapat diketahui pengaruhnya terhadap nilai perusahaan (Puspitaningtyas, 2017). Kebijakan dividen berperan dalam meningkatkan komposisi modal perusahaan dan hal ini berimplikasi terhadap nilai perusahaan sehingga kebijakan dividen mampu memperkuat hubungan leverage dan nilai perusahaan (Khairani et al., 2018; Burhanuddin \& Nuraini, 2018).

Berdasarkan pembahasan sebelumnya maka hipotesis dapat dirumuskan sebagai berikut.

$\mathrm{H}_{1}$ : Profitabilitas berpengaruh positif dan signifikan terhadap nilai perusahaan manufaktur di Bursa Efek Indonesia

$\mathrm{H}_{2}$ : Likuiditas berpengaruh positif dan signifikan terhadap nilai perusahaan manufaktur di Bursa Efek Indonesia

$\mathrm{H}_{3}$ : Leverage berpengaruh positif dan signifikan terhadap nilai perusahaan manufaktur di Bursa Efek Indonesia

$\mathrm{H}_{4}$ : Kebijakan dividen berpengaruh positif dan signifikan terhadap nilai perusahaan manufaktur di Bursa Efek Indonesia.

$\mathrm{H}_{5}$ : Kebijakan dividen mampu memoderasi pengaruh profitabilitas terhadap nilai perusahaan manufaktur di Bursa Efek Indonesia

$\mathrm{H}_{6}$ : Kebijakan dividen mampu memoderasi pengaruh likuiditas terhadap nilai perusahaan manufaktur di Bursa Efek Indonesia

$\mathrm{H}_{7}$ : Kebijakan dividen mampu memoderasi pengaruh leverage terhadap nilai perusahaan manufaktur di Bursa Efek Indonesia 


\section{METODE}

Sesuai dengan judul penelitian yang dipilih, maka objek penelitian ini adalah profitabilitas, struktur modal, kepemilikan manajerial, nilai perusahaan dan return saham pada Perusahaan Pertanian terdaftar di Bursa Efek Indonesia (BEI). Adapun yang menjadi lokasi penelitian ini adalah Bursa Efek Indonesia dengan mengakses situs resminya yaitu www.idx.co.id.

Adapun populasi yang akan diteliti dalam penelitian ini adalah seluruh perusahaan manufaktur yang terdaftar di BEI, yaitu sebanyak 145. Teknik pengambilan sampel yang digunakan adalah purposive sampling.

Adapun kriteria yang ditentukan untuk pemilihan sampel dalam penelitian ini disajikan pada Tabel di bawah ini:

\section{Tabel 1}

Kriteria Pengambilan Sampel

\begin{tabular}{llc}
\hline No & Kriteria & $\begin{array}{c}\text { Jumlah } \\
\text { Perusahaan }\end{array}$ \\
\hline 1 & $\begin{array}{l}\text { Jumlah Perusahaan Manufaktur } \\
\text { di BEI per 31 Des 2018 }\end{array}$ \\
2 & $\begin{array}{l}\text { Perusahaan manufaktur yang } \\
\text { delisting selama periode 2014 - }\end{array}$ \\
3 & $\begin{array}{l}\text { 2018 } \\
\text { Perusahaan yang tidak memiliki }\end{array}$ \\
& $\begin{array}{l}\text { laporan keuangan } \\
\text { Perusahaan manufaktur yang } \\
\text { tidak membayar dividen secara } \\
\text { regular } \\
\text { Perusahaan manufaktur yang } \\
\text { membayar dividen secara ruting } \\
\text { untuk periode 2014 -2018 }\end{array}$ \\
\hline
\end{tabular}

Sumber : Bursa Efek Indonesia, 2019

Berdasarkan tabel 1, maka banyaknya sampel dalam penelitian ini sebanyak 28 perusahaan. Adapun definisi operasional dalam penelitian ini adalah sebagai berikut :

Tabel 2

\section{Definisi Operasional Variabel}

\begin{tabular}{lll}
\hline Variabel & Proksi & Formulasi \\
\hline
\end{tabular}




\begin{tabular}{|c|c|c|}
\hline $\begin{array}{l}\text { Nilai } \\
\text { Perusahaan }\end{array}$ & $\begin{array}{l}\text { Tobins } Q \\
\text { merupakan } \\
\text { pengukuran } \\
\text { yang dapat } \\
\text { dihitung dengan } \\
\text { mencari } \\
\text { kapitalisasi } \\
\text { pasar dikurangi } \\
\text { dengan total } \\
\text { hutang dan } \\
\text { dibagi dengan } \\
\text { total asset. }\end{array}$ & 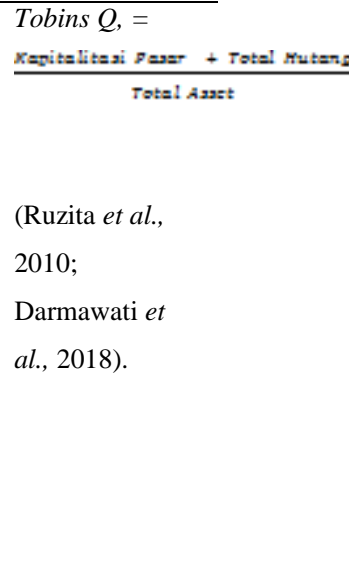 \\
\hline Profitabilitas & $\begin{array}{l}\text { Return on } \\
\text { Assets (ROA) } \\
\text { yang } \\
\text { merupakan } \\
\text { perbandingan } \\
\text { laba bersih dan } \\
\text { total aset }\end{array}$ & 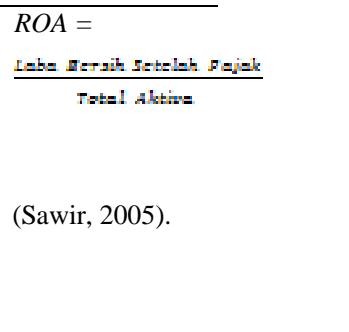 \\
\hline Likuiditas & $\begin{array}{l}\text { Current Ratio } \\
\text { (CR) yang } \\
\text { merupakan } \\
\text { kemampuan } \\
\text { suatu } \\
\text { perusahaaan } \\
\text { dalam } \\
\text { memenuhi } \\
\text { kewajiban } \\
\text { jangka } \\
\text { pendeknya } \\
\text { secara tepat } \\
\text { wakru }\end{array}$ & $\begin{array}{l}\text { Current Ratio } \\
= \\
\text { DurrentAmsts } \\
\text { Eurrent Lisbillties } \\
\text { (Darsono, } \\
2007) .\end{array}$ \\
\hline leverage & $\begin{array}{l}\text { Debt to Assets } \\
\text { Ratio (DAR) } \\
\text { yang } \\
\text { merupakan } \\
\text { utang yang } \\
\text { digunakan } \\
\text { untuk } \\
\text { mengukur } \\
\text { perbandingan } \\
\text { antara total } \\
\text { utang dengan } \\
\text { total aktiva }\end{array}$ & $\begin{array}{l}\text { (Novianto \& } \\
\text { Asandimitra, } \\
\text { 2017; Nilayanti } \\
\text { \& Suaryana, } \\
\text { 2019). }\end{array}$ \\
\hline $\begin{array}{l}\text { Kebijakan } \\
\text { Deviden }\end{array}$ & $\begin{array}{l}\text { Dividend } \\
\text { Payout ratio } \\
\text { (DPR) yang } \\
\text { merupakan } \\
\text { perbandingan } \\
\text { antara dividen }\end{array}$ & $\begin{array}{l}\text { Dividend } \\
\text { payout ratio = } \\
\text { Amiden Fer share } \\
\text { Rerning Fer ytars } \\
\text { (Basri dan } \\
\text { Indriyo, 2012). }\end{array}$ \\
\hline
\end{tabular}




\begin{tabular}{ll}
\hline yang \\
dibayarkan \\
dengan laba \\
bersih yang \\
didapatkan dan \\
biasanya \\
disajikan dalam \\
bentuk \\
persentase. \\
\hline
\end{tabular}

Adapun persamaan regresi yang akan diuji adalah sebagai berikut:

Direct Model :

Model 1 (Menguji $\mathrm{H}_{1}-\mathrm{H}_{3}$ ):

Tobins_ $\mathrm{Q}_{i t}=\beta_{0}+\beta_{1} \mathrm{ROA}_{\mathrm{it}}+\beta_{2} \mathrm{CR}_{\mathrm{it}}+\beta_{3} \mathrm{DAR}_{\mathrm{it}}+\mathrm{e}_{\mathrm{it}}$

Model 2 (Menguji $\mathrm{H}_{4}$ ):

Tobins_ $\mathrm{Q}_{i t}=\beta_{0}+\beta_{1} \mathrm{ROA}_{\mathrm{it}}+\beta_{2} \mathrm{CR}_{\mathrm{it}}+\beta_{3} \mathrm{DAR}_{\mathrm{it}}+\beta_{4} \mathrm{DPR}_{\mathrm{it}}+\mathrm{e}_{\mathrm{it}}$

Model 3 (Menuguji $\mathrm{H}_{5}-\mathrm{H}_{7}$ ):

Tobins_ $\mathrm{Q}_{i t}=\beta_{0}+\beta_{1} \mathrm{ROA}_{\mathrm{it}}+\beta_{2} \mathrm{CR}_{\mathrm{it}}+\beta_{3} \mathrm{DAR}_{\mathrm{it}}+\beta_{4} \mathrm{DPR}_{\mathrm{it}}+\beta_{5} \mathrm{ROA}^{*} \mathrm{DPR}_{\mathrm{it}}+\beta_{6} \mathrm{CR}^{*} \mathrm{DPR}_{\mathrm{it}}+$ $\beta_{7} \mathrm{DAR}^{*} \mathrm{DPR}_{\mathrm{it}}+\mathrm{e}_{\mathrm{it}}$

\section{HASIL PENELITIAN DAN PEMBAHASAN}

Analisis Deskriptif Statistik

Pada analisis statistik deskriptif, akan terlihat bagaimana nilai rata-rata, nilai standar deviasi, nilai maksimum dan nilai minimum dari data yang digunakan dalam penelitian ini. Adapun hasil analisis deskriptif dalam penelitian ini adalah sebagai berikut:

Tabel 3

Analisis Deskriptif Statistik

\begin{tabular}{|c|c|c|c|c|c|}
\hline & $\begin{array}{c}\text { TOBINS } \\
\text { Q }\end{array}$ & ROA & $\mathrm{CR}$ & DAR & DPR \\
\hline Mean & 3.3189 & 0.1091 & 2.3653 & 0.4262 & 0.4168 \\
\hline Std. Dev. & 4.1532 & 0.1077 & 1.9586 & 0.1793 & 0.4670 \\
\hline Maximum & 23.2857 & 0.5267 & 12.9946 & 0.7525 & 4.0376 \\
\hline Minimum & 0.4874 & -0.0441 & 0.5139 & 0.0661 & -1.2296 \\
\hline Observasi & 140 & 140 & 140 & 140 & 140 \\
\hline
\end{tabular}

Sumber : Data Diolah, 2019

Keterangan : Mean adalah nilai rata-rata. SD adalah standard deviasi. Max adalah nilai tertinggi. Min adalah niai terendah. Obs adalah jumlah pengamatan. 
Berdasarkan Tabel 3 di atas, terlihat bahwa nilai rata-rata untuk variabel nilai perusahaan (diproksikan dengan Tobins Q) dalam penelitian ini sebesar 3.3189 dengan standar deviasi sebesar 4.1532. Nilai rata-rata lebih rendah dibandingkan nilai standar deviasinya, sehingga dapat disimpulkan bahwa data Tobins $\mathrm{Q}$ dalam penelitian ini memiliki fluktuasi yang tergolong tinggi. Nilai tertinggi Tobins Q sebesar 23.2857 dengan nilai terendahnya sebesar 0.4874 untuk 140 observasi.

Selanjutnya, profitabilitas (diproksikan dengan ROA) dalam penelitian ini memiliki nilai ratarata sebesar 0.1091 dengan standar deviasi sebesar 0.1077, dimana nilai rata-rata berada di atas nilai standar deviasi, sehingga dapat disimpulkan bahwa data profitabilitas dalam penelitian ini memiliki fluktuasi yang tergolong kecil. Nilai tertinggi profitabilitas dalam penelitian ini sebesar 0.5267 dengan nilai terendahnya sebesar -0.0441 yang dilakukan terhadap 140 observasi.

Nilai rata-rata rasio likuditas (diproksikan dengan CR) dalam penelitian ini sebesar 2.3653 dengan standar deviasi sebesar 1.9586. Nilai tersebut menunjukkan bahwa likuiditas dalam penelitian ini memiliki rata-rata lebih tinggi dibandingkan dengan standar deviasinya, sehingga dapat disimpulkan bahwa fluktuasi data likuiditas dalam penelitian ini tergolong dalam fluktuasi yang kecil. Nilai tertinggi likuiditas dalam penelitian ini sebesar 12.9946 dan nilai terendahnya sebesar 0.5139 yang dilakukan terhadap 140 observasi.

Selanjutnya, nilai rata-rata leverage (diproksikan dengan DAR) sebesar 0.4262 dengan standar deviasinya sebesar 0.1793 , dimana nilai rata-rata berada di atas standar deviasi yang menunjukkan bahwa fluktuasi leverage dalam penelitian ini tergolong kecil. Nilai tertinggi leverage adalah 0.7525 dan nilai terendahnya sebesar 0.0661 dengan jumlah observasi sebanyak 140 observasi.

Selanjutnya, rata-rata nilai kebijakan dividen (diproksikan dengan DPR) dalam penelitian ini sebesar 0.4168 dan nilai standar deviasinya sebesar 0.4670 , dimana nilai rata-rata berada di bawah nilai standar deviasi yang menunjukkan bahwa fluktuasi data kebijakan dividen dalam penelitian ini tergolong tinggi. Penelitian ini memiliki nilai tertinggi kebijakan dividen mencapai 4.0376 dan nilai terendahnya sebesar -1.2296 dengan jumlah pengamatan sebanyak 140 observasi.

\section{Analisis Korelasi}

Analisis korelasi merupakan tahapan pengujian untuk melihat hubungan (korelasi) dari setiap variabel yang digunakan dalam penelitian ini. Adapun hasil analisis korelasi dalam penelitian ini dapat dilihat sebagai berikut: 


\section{Tabel 4}

\section{Analisis Korelasi}

\begin{tabular}{|c|c|c|c|c|c|}
\hline & TOBINS_Q & $\mathrm{ROA}$ & $\overline{\mathrm{CR}}$ & DAR & $\overline{D P R}$ \\
\hline TOBINS_ & 1.0000 & & & & \\
\hline Q & ----- & & & & \\
\hline \multirow{3}{*}{ ROA } & 0.8604 & 1.0000 & & & \\
\hline & $(19.8338)^{* *}$ & & & & \\
\hline & $*$ & ------ & & & \\
\hline \multirow{2}{*}{ CR } & -0.0572 & 0.0844 & 1.0000 & & \\
\hline & $(-0.6732)$ & (0.9957) & ----- & & \\
\hline \multirow{2}{*}{ DAR } & 0.1344 & -0.0559 & -0.7449 & 1.0000 & \\
\hline & (1.5934) & $(-0.6584)$ & $(-13.1180) * * *$ & ----- & \\
\hline \multirow{4}{*}{ DPR } & 0.2903 & 0.3076 & 0.2159 & -0.2419 & 1.0000 \\
\hline & & & & $(-$ & \\
\hline & & $(3.7989)^{*}$ & & 2.9292) & \\
\hline & $(3.5640) * * *$ & $* *$ & $(2.5982) * *$ & $* * *$ & ----- \\
\hline
\end{tabular}

Sumber : Data Diolah, 2019

Keterangan : $* * *, * *, *$ adalah level signifikan masing-masing pada $1 \%, 5 \%$ dan $10 \%$.

Berdasarkan Tabel 4 di atas, terlihat bahwa profitabilitas dan kebijakan dividen berkorelasi positif dengan nilai perusahaan masing-masing sebesar 0.8604 dan 0.2903 dan signifikan pada level $1 \%$, sedangkan leverage juga berkorelasi positif dengan nilai perusahaan sebesar 0.1344 , namun nilai tersebut tidak tergolong signifikan secara statistik. Adapun likuiditas berkorelasi negatif dengan nilai perusahaan sebesar -0.0572 namun tidak signifikan.

Untuk korelasi/hubungan antar variabel bebas, terlihat pada Tabel 5.2 bahwa kebijakan dividen berkorelasi positif dengan profitabilitas sebesar 0.3076 dan signifikan pada level $1 \%$, sedangkan likuiditas juga berkorelasi positif dengan profitabilitas sebesar 0.0844 namun belum tergolong signifikan secara statistik. Leverage berkorelasi negatif dan signifikan terhadap profitabilitas sebesar -0.0559 tetapi tidak signifikan. Leverage berkorelasi negatif dengan likuiditas sebesar -0.7449 dan signifikan pada level 1\%, sedangkan kebijakan dividen berkorelasi positif dengan likuiditas sebesar 0.2159 dan signifikan pada level 5\%. Adapun Kebijakan dividen berkorelasi negatif dengan leverage sebesar -0.2419 dan signifikan pada level $1 \%$.

\section{Teknik Pemilihan Model}

Agar model yang digunakan baik dan sesuai, maka diperlukan penaksiran model. Terdapat tiga model di dalam regresi data panel yaitu Common Effect Model (CEM) atau Pooled Least Square, Fixed Effect Model (FEM) dan Random Effect Model (REM). Untuk menentukan model terbaik dan 
yang sesuai dengan penelitian ini, maka uji yang dilakukan yaitu Uji Chow dan Uji Hausman. Uji Chow dilakukan untuk membandingkan model CEM dan FEM sedangkan Uji Hausman dilakukan untuk membandingkan FEM dan REM.

\section{Tabel 5}

Uji Chow

\begin{tabular}{lrrr}
\hline & \multicolumn{1}{c}{ Model 1 } & \multicolumn{1}{c}{ Model 2 } & \multicolumn{1}{c}{ Model 3 } \\
\hline Chi Squre & 29.0192 & 30.3281 & 33.2967 \\
Probability & 0.3600 & 0.2996 & 0.1875
\end{tabular}

Sumber : Data Diolah, 2019

Berdasarkan tabel 5, terlihat bahwa nilai probabilitas Uji Chow puntuk Model 1 (0.3600), Model 2 (0.2996), serta Model 3 (0.1875) seluruhnya berada di atas nilai toleransi kesalahan dalam penelitian ini (0.05). Dengan kata lain, hasil Uji Chow menyatakan bahwa Common Effect model (CEM) menjadi model yang tepat dalam penelitian ini, sehingga dilanjutkan dengan Uji LM untuk membandingkan CEM dan REM.

Tabel 6

\section{Uji LM}

\begin{tabular}{lcrr}
\hline & \multicolumn{1}{c}{ Model 1 } & \multicolumn{1}{c}{ Model 2 } & \multicolumn{1}{c}{ Model 3 } \\
\hline Breusch-Pagan Value & 0.2661 & 0.1349 & 0.0052 \\
Probability & 0.6059 & 0.7133 & 0.9423
\end{tabular}

Sumber : Data Diolah, 2019

Berdasarkan tabel 6, terlihat bahwa nilai probabilitas Uji LM untuk Model 1 (0.6059), Model 2 (0.7133) dan Model 3 (0.9423) seluruhnya berada di atas nilai toleransi kesalahan dalam penelitian ini (0.05). Dengan kata lain, Hasil Uji LM menunjukkan bahwa model yang tepat adalah Common Effect Model (CEM), sehingga pengujian asumsi klasik, estimasi regresi dan pengambilan keputusan pengujian hipotesis dilakukan dengan Common Effect Model (CEM).

\section{Uji Asumsi Klasik}

\section{Uji Normalitas}

Uji normalitas digunakan untuk menguji model regresi mempunyai distribusi normal atau tidak. Uji normalitas yang dilakukan di dalam penelitian ini adalah Uji Jarque Bera. Pada Uji Jarque Bera, nilai yang dilihat adalah nilai probability. Suatu model regresi dikatakan memenuhi asumsi normalitas jika nilai probability lebih besar dari pada nilai standar toleransi kesalahan yaitu 0,05 . Adapun hasil Uji normalitas disajikan pada Tabel 6 di bawah ini:

Tabel 7

Uji Normalitas

\begin{tabular}{lccc}
\hline & Model 1 & Model 2 & Model 3 \\
\hline JB-Statistik & 225.7913 & 246.1033 & 168.1416
\end{tabular}




\begin{tabular}{llll} 
Probability & 0.0000 & 0.0000 & 0.0000 \\
\hline
\end{tabular}

Sumber : Data Diolah, 2019

Berdasarkan tabel 7 di atas, ditemukan bahwa nilai probability untuk ketiga model yang diuji dalam penelitian ini memiliki nilai probability sebesar 0,0000 dimana nilai tersebut berada di bawah nilai toleransi kesalahan dalam penelitian ini sehingga dapat disimpulkan bahwa data dalam penelitian ini tidak terdistribusi secara normal. Akan tetapi, dikarenakan jenis data yang digunakan di dalam penelitian ini adalah data panel dimana setiap cross section atau objek penelitian memiliki tren data yang berbeda-beda sehingga problem normalitas dapat diabaikan.

\section{Uji Heteroskedastisitas}

Uji heteroskedastisitas merupakan salah satu uji asumsi klasik yang bertujuan untuk menguji apakah dalam model regresi terjadi ketidaksamaan varian residual antara yang satu dengan yang lain. Jika varian residual dari satu pengamatan ke pengamatan yang lain tetap maka disebut homoskedastisitas dan jika varians berbeda maka disebut heteroskedastisitas (Ghozali, 2011).

Uji heteroskedastisitas yang digunakan di dalam penelitian ini adalah Uji Glajset dimana tahapannya yaitu membentuk nilai absolut dari residual dan melakukan regresi pada seluruh variabel bebas terhadap nilai tersebut (Widarjono, 2017). Hasil Uji Glajser dalam penelitian ini disajikan pada tabel di bawah ini:

\section{Tabel 8}

Uji Heteroskedastisitas

\begin{tabular}{cccc}
\hline Variabel & $\begin{array}{c}\text { Model 1 } \\
\text { (Probability) }\end{array}$ & $\begin{array}{c}\text { Model 2 } \\
\text { (Probability) }\end{array}$ & $\begin{array}{c}\text { Model 3 } \\
\text { (Probability) }\end{array}$ \\
\hline C & 0.3182 & 0.3681 & 0.1107 \\
ROA & 0.0760 & 0.0710 & 0.1568 \\
CR & 0.4725 & 0.3590 & 0.2664 \\
DAR & 0.9742 & 0.8941 & 0.4494 \\
DPR & ---- & 0.6366 & 0.2404 \\
ROA*DPR & ---- & --- & 0.0924 \\
CAR*DPR & ---- & ---- & 0.2514 \\
DAR*DPR & ---- & ---- & 0.3584 \\
\hline
\end{tabular}

Keterangan $\quad: * * *, * *, *$ adalah level signifikan masing-masing pada $1 \%, 5 \%$ dan $10 \%$.

Berdasarkan tabel 8 , terlihat bahwa seluruh nilai probability untuk variabel bebas berada di atas 0,05 sehingga dapat disimpulkan bahwa model yang digunakan dalam penelitian ini terbebas dari gejala heteroskedastisitas.

\section{Uji Multikolinearitas}

Uji multikolinearitas adalah salah satu uji di dalam asumsi klasik berutujuan untuk melihat adanya atau tidaknya korelasi antar variabel independen di dalam penelitian. Ghozali (2011) mengatakan bahwa model yang baik adalah model dimana antar variabel bebas tidak memiliki 
kolerasi. Gujarati \& Porter (2009) menambahkan bahwa nilai korelasi antara nilai korelasi antara variabel bebas harus berada di bawah 0,8 .

Uji multikolinearitas di dalam penelitian ini dilakukan dengan melihat nilai korelasi antara variabel bebas Pada Tabel 4 Hasil Uji Korelasi. Terlihat bahwa seluruh cell antara variabel bebas di dalam penelitian ini memiliki nilai korelasi yang berada di bawah 0,8. Maka dari itu, dapat disimpulkan bahwa tidak terjadi gejala multikolenearitas di dalam penelitian ini, artinya antara seluruh variabel bebas dalam penelitian ini tidak memiliki korelasi yang tinggi.

\section{Uji Autokorelasi}

Uji autokorelasi bertujuan untuk menguji dalam suatu model ada atau tidaknya korelasi antara kesalahan pengganggu pada periode $t$ dengan kesalahan pada periode t-1. Ghozali (2011) mengatakan bahwa model regresi yang baik adalah model yang tidak terdapat autokorelasi di dalamnya. Adapun hasil uji autokorelasi disajikan pada tabel di bawah ini:

\section{Tabel 9}

\section{Uji Autokorelasi}

\begin{tabular}{lccc}
\hline & Model 1 & Model 2 & Model 3 \\
\hline Durbin & 2.0134 & 2.0279 & 2.0275 \\
Watson & & & \\
& & &
\end{tabular}

Sumber : Data Diolah, 2019

Berdasarkan Tabel 9 di atas, ditemukan bahwa nilai Durbin Watson untuk Model 1 (2.0134), Model 2 (2.0279) serta Model 3 (2.0275) masing-masing berada bergerak menuju angka 2. Dengan kata lain, ketiga model yang digunakan dalam penelitian ini terbebas dari gejala autokorelasi.

\section{Estimasi Regresi Linear Berganda}

Hasil pemilihan model menunjukkan bahwa model yang tepat untuk diestimasikan dalam penelitian ini adalah Common Effect Model. Adapun hasil regresi secara Common Effect Model (CEM) baik untuk Direct Model maupun Interaction Model dapat dilihat pada tabel di bawah in

Tabel 10

Estimasi Regresi Data Panel dengan Common Effect Model

\begin{tabular}{ccrrrrr}
\hline Variabel & \multicolumn{2}{c}{ Model 1 } & \multicolumn{2}{c}{ Model 2 } & \multicolumn{2}{c}{ Model 3 } \\
\cline { 2 - 7 } Independen & Koefisien & \multicolumn{1}{c}{$\mathrm{t}_{\text {hitung }}$} & Koefisien & \multicolumn{1}{c}{$\mathrm{t}_{\text {hitung }}$} & Koefisien & \multicolumn{1}{c}{$\mathrm{t}_{\text {hitung }}$} \\
\hline C & -2.3075 & $-2.6067 * *$ & -2.6233 & $-2.9275^{* * *}$ & 1.0717 & 0.6961 \\
ROA & 33.5282 & $21.2580^{* * *}$ & 32.6498 & $19.8960^{* * *}$ & 25.3873 & $8.1779 * * *$ \\
CR & 0.0271 & 0.2088 & 0.0185 & 0.1436 & -0.4865 & $-1.9871 * *$ \\
DAR & 4.4606 & $3.1510^{* * *}$ & 4.7972 & $3.3849 * * *$ & 0.3405 & 0.1636 \\
DPR & ---- & ---- & 0.6921 & $1.7773^{*}$ & -7.1600 & $-2.1989 * *$ \\
ROA*DPR & ---- & ---- & ---- & --- & 9.6305 & $2.5282^{* *}$ \\
CR*DPR & ---- & ---- & ---- & --- & 1.0906 & $2.2693 * *$ \\
DAR*DPR & ---- & ---- & ---- & ---- & 10.0894 & $2.2083 * *$ \\
\hline R-squared & \multicolumn{7}{c}{0.7738} & & 0.7789 & & 0.7969
\end{tabular}




$\begin{array}{lrrr}\text { Adjusted R-squared } & 0.7688 & 0.7724 & 0.7861 \\ \text { F-statistic } & 155.0853 * * * & 118.9500 * * * & 74.0168 * * * \\ \text { Durbin-Watson } & 2.0134 & 2.0279 & 2.0275\end{array}$

Keterangan $\quad: * * *, * *, *$ adalah level signifikan masing-masing pada $1 \%, 5 \%$ dan $10 \%$.

Berdasarkan tabel 10 di atas, maka persamaan regresi yang dapat dibentuk Berdasarkan tabel di atas, maka persamaan regresi yang dapat dibentuk adalah sebagai berikut:

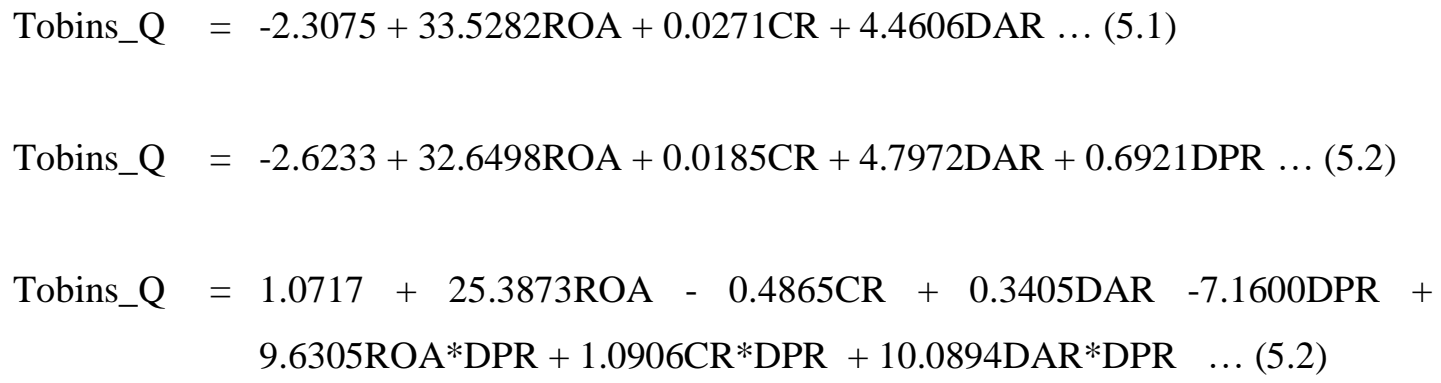

Berdasarkan Persamaan 5.1 di atas, terlihat bahwa nilai konstanta sebesar -2.3075 yang menunjukkan bahwa ketika profitabilitas, likuiditas dan leverage bernilai 0 , maka nilai perusahaan akan tetap konstan dengan nilai 2.3075. Kemudian, profitabilitas memiliki nilai koefisien positif sebesar 33.5282. Hal ini menunjukkan bahwa ketika profitabilitas naik 1\%, maka nilai perusahaan akan bertambah sebesar 33.5282. Nilai koefisien tersebut juga tergolong signifikan pada level 1\% ( $p$ value < 0.01). Dengan kata lain, profitabilitas berpengaruh positif dan signifikan terhadap nilai perusahaan manufaktur di BEI, sehingga $\mathrm{H}_{1}$ diterima.

Selanjutnya, rasio likuiditas pada Persamaan 5.1 memiliki koefisien sebesar 0.0271. Nilai tersebut menunjukkan bahwa ketika likuiditas naik 1\%, maka nilai perusahaan akan bertambah sebesar 0.0271. Akan tetapi, nilai tersebut tidak tergolong signifikan secara statistik. Dengan kata lain, rasio likuiditas berpengaruh positif tetapi tidak signifikan terhadap nilai perusahaan sektor manufaktur di BEI, sehingga $\mathrm{H}_{2}$ ditolak. Berbeda halnya dengan pengaruh leverage terhadap nilai perusahaan dengan koefisien positif sebesar 4.4606. Nilai tersebut menunjukkan bahwa ketika leverage ditingkatkan $1 \%$, maka nilai perusahaan akan bertambah sebesar 4.4606. Nilai tersebut juga tergolong signifikan secara statistik pada level 1\% ( $p$-value < 0.01). Dengan kata lain, leverage berpengaruh positif dan signifikan terhadap nilai perusahaan sektor manufaktur di BEI, sehingga $\mathrm{H}_{3}$ diterima.

Untuk melihat pengaruh kebijakan dividen terhadap nilai perusahaan, maka persamaan empiris yang akan diinterprestasikan adalah Persamaan 5.2. Berdasarkan Persamaan 5.2, terlihat bahwa nilai koefisien kebijakan dividen (DPR) sebesar 0.6921, yang memiliki arti bahwa ketika kebijakan dividen naik 1\%, maka nilai perusahaan akan bertambah sebesar 0.6921. Selanjutnya, nilai tersebut juga tergolong signifikan pada level 10\% ( $p$-value < 0.1$)$. Maka dari itu, kebijakan dividen berpengaruh positif dan signifikan terhadap nilai perusahaan sektor manufaktur di BEI, sehingga $\mathrm{H}_{4}$ diterima. 
Untuk pengaruh secara moderasi, maka hasil pengujian empiris disajikan pada Persamaan 5.3. Berdasarkan Persamaan 5.3, nilai koefisien untuk ROA*DPR sebesar 9.6305. Hal ini menunjukkan bahwa ketika kebijakan dividen meningkat, maka profitabilitas akan memberikan pengaruh positif terhadap nilai perusahaan, dikarenakan koefisien statistik yang dihasilkan positif. Nilai koefisien tersebut juga tergolong signifikan secara statistik di level 5\% ( $p$-value $<0.05)$. Dengan kata lain, kebijakan dividen mampu memoderasi pengaruh profitabilitas terhadap nilai perusahaan manufaktur di BEI, sehingga $\mathrm{H}_{5}$. Berdasarkan kriteria yang dikemukakan oleh Sharma et al. (1981), maka kebijakan dividen tergolong dalam kategori quacy moderator, dikarenakan memberikan pengaruh yang signifikan, baik secara prediktor maupun moderator. Selanjutnya, pada Persamaan 5.3, pengaruh profitabilitas terhadap nilai perusahaan secara langsung juga bernilai positif. Ini menunjukkan bahwa profitabilitas akan memberikan pengaruh positif untuk seluruh nilai kebijakan dividen.

Selanjutnya, nilai koefisien CR*DPR sebesar 1.0906. Hal tersebut menunjukkan bahwa likuiditas akan memberikan pengaruh positif terhadap nilai perusahaan pada saat terjadi peningkatan nilai kebijakan dividen, dikarenakan koefisien regresi yang dihasilkan bernilai positif. Selain itu, nilai probability juga tergolong signifikan di level 5\%, sehingga dapat disimpulkan bahwa kebijakan dividen mampu memoderasi pengaruh likuiditas terhadap nilai perusahaan manufaktur di BEI, sehingga $\mathrm{H}_{6}$ diterima. Pada alur hubungan ini, kebijakan dividen juga tergolong dalam quacy moderator, dikarenakan berpengaruh signifikan baik secara prediktor maupun sebagai moderator (Sharma et al., 1981). Selanjutnya, likuiditas akan memberikan pengaruh positif terhadap nilai perusahaan ketika skor kebijakan dividen > 0.4461. Tetapi ketika skor kebijakan dividen berada < 0.4461, maka likuiditas akan memberikan pengaruh negatif terhadap nilai perusahaan. Nilai kebijakan dividen sebesar $\mathbf{0 . 4 4 6 1}$ diperoleh berdasarkan penggalan persamaan dari Tabel 5.8 untuk Persamaan 5.3 (Model 3) yaitu Tobins $\mathbf{Q}=\ldots . . .(\mathbf{- 0 . 4 8 6 5}+\mathbf{1 . 0 9 0 6 D P R}) * \mathbf{C R}$ dengan syarat $\mathbf{- 0 . 4 8 6 5}+$ 1.0906DPR = 0, sehingga hasil perhitungannya adalah $\mathrm{DPR}=\mathbf{0 . 4 8 6 5 / 1 . 0 9 0 6}=\mathbf{0 . 4 4 6 1}$.

Berdasarkan Persamaan 5.3, nilai koefisien DAR*DPR sebesar 10.0894. Hal ini menunjukkan bahwa ketika kebijakan dividen meingkat, maka leverage akan memberikan pengaruh positif terhadap nilai perusahaan. Nilai tersebut juga tergolong signifikan secara statistik pada level 5\%. Dengan kata lain, kebijakan dividen mampu memoderasi pengaruh leverage terhadap nilai perusahaan sektor manufaktur di BEI, sehingga $\mathrm{H}_{7}$ diterima. Selanjutnya, pada Persamaan 5.3 pengaruh leverage secara langsung terhadap nilai perusahaan juga memiliki nilai koefisien positif (sama dengan koefisien moderasinya). Maka dari itu, leverage memberikan pengaruh positif terhadap nilai perusahaan untuk seluruh level/skor kebijakan dividen.

\section{Pembahasan}

\section{Pengaruh Profitabilitas terhadap Return Saham}

Berdasarkan hasil estimasi regresi dengan menggunakan common effect model, maka diperoleh hasil bahwa profitabilitas berpengaruh positif dan signifikan terhadap nilai perusahaan. Hasil ini juga sejalan dengan ekspektasi serta teori yang penulis bangun bahwasanya profitabilitas 
menjadi aspek yang dapat meningkatkan nilai perusahaan, sehingga $\mathrm{H}_{1}$ diterima. Ini juga memberikan bukti empiris bahwa profiabilitas merupakan prediktor dalam meningkatkan nilai perusahaan.

Hasil penelitian ini sejalan dan mendukung Signalling Theory yang menyatakan bahwa laba menjadi informasi yang dapat memancarkan sinyal positif ke pasar sehingga nilai perusahaan meningkat (Ross, 1977). Perusahaan dengan laba yang tinggi menjadi perusahaan yang menarik investor, dan nilai perusahaan meningkat. Darmawati et al. (2018) juga berpendapat bahwa profitabilitas dapat dijadikan patokan kinerja buku atau kinerja akuntansi perusahaan, sehingga kinerja yang baik akan memberikan sinyal positif dan menaikkan nilai perusahaan. Perusahaan yang dapat memberikan informasi laba dan keuntungannya akan lebih mudah direspon oleh pasar dan terjadi kenaikan harga saham yang berdampak pada nilai perusahaan (Koerniadi \& Tourani-Rad, 2008). Dengan kata lain, profitabilitas berpengaruh positif dan signifikan terhadap nilai perusahaan.

Hasil penelitian yang menemukan bahwa profitabilitas berpengaruh positif terhadap nilai perusahaan juga didukung oleh beberapa studi sebelumnya, seperti hasil riset Patricia et al., (2018) dan Le (2019) yang menemukan bahwa profitabilitas berpengaruh positif terhadap nilai perusahaan. Akan tetapi, hasil ini bertentangan dengan temuan Ihsan \& Sanjani (2015) dan Setiadi (2017) yang menemukan bahwa profitabilitas tidak berpengaruh signifikan terhadap nilai perusahaan.

\section{Pengaruh Likuiditas terhadap Nilai Perusahaan}

Berdasarkan hasil analisis data yang telah dilakukan dengan common effect model, penelitian ini telah membuktikan bahwa likuiditas berpengaruh positif tetapi tidak signifikan terhadap nilai perusahaan sektor manufaktur di BEI. Meskipun nilai koefisien yang diperoleh positif, dimana hal tersebut telah sejalan dengan ekspektasi penulis, tetapi pengaruhnya belum tergolong signifikan secara statistik, sehingga $\mathrm{H}_{2}$ ditolak. Ini juga membuktikan bahwa likuiditas tidak berpengaruh signifikan terhadap nilai perusahaan.

Pada dasarnya likuiditas merupakan kemampuan perusahaan dalam memenuhi kewajiban jangka pendeknya (Kasmir, 2015). Akan tetapi, likuiditas yang tinggi juga menunjukkan banyak dana perusahaan yang menganggur yang pada akhirnya mengurangi kemampuan laba perusahaan (Hasanah, 2018). Selanjutnya, hutang jangka pendek merupakan hutang yang memiliki jangka waktu di bawah 1 tahun, bahkan hutang jangka pendek hanya memiliki masa waktu 1 hari, dan hal tersebut membuat tingkat likuiditas tidak terlalu dilihat oleh pasar karena kurang relevan (Hidayat, 2019). Hidayat (2019) juga menambahkan bahwa likuiditas hanya dapat memberikan dampak yang signifikan pada perusahaan pada kondisi undervalue, tetapi tidak pada perusahaan pada kondisi overvaleu. Berdasarkan hasil analisis deskriptif dalam penelitian ini, perusahaan manufaktur di BEI untuk periode 2014-2018 memiliki nilai rata-rata sebesar 3,3189 dimana nilai tersebut berada di atas 1 dan tergolong dalam kondisi overvalue (Kaldor, 1966; Tobin, 1969). Hal tersebut menunjukkan bahwa likuiditas tidak berpengaruh signifikan terhadap nilai perusahaan.

Riset sebelumnya juga membuktikan bahwa likuiditas bukanlah suatu indikator penilaian investor di pasar modal (Astutik, 2017). Hal ini dapat saja terjadi pada kondisi pasar modal di 
emerging market, dimana hutang jangka pendek bukanlah elemen yang dinilai oleh pasar (Betten \& Vo, 2019). Selain itu, likuiditas yang tinggi memberikan indikasi bahwa aset lebih banyak digunakan untuk membayar hutang dan mengurangi laba, sehingga hal tersebut tidak dapat dijadikan patokan oleh investor di pasar modal (Annisa \& Chabacib, 2017). Uraian tersebut mendukung hasil penelitian ini yang membuktikan bahwa likuiditas tidak berpengaruh signifikan terhadap nilai perusahaan.

Hasil penelitian ini sejalan dengan temuan Umaiyah \& Salim (2018) Hasanah (2018), Pascerano (2017) yang menemukan bahwa likuiditas tidak berpengaruh signifikan terhadap nilai perusahaan. Akan tetapi, hasil penelitian ini bertolak belakang dengan temuan Lubis et al., (2013) dan Rudianto (2019) yang menemukan bahwa likuiditas berpengaruh positif dan signifikan terhadap nilai perusahaan.

\section{Pengaruh Leverage terhadap Nilai Perusahaan}

Berdasarkan hasil estimasi regresi yang telah dilakukan, maka penelitian ini memberikan bukti empiris bahwa leverage berpengaruh positif dan signifikan terhadap nilai perusahaan. Hasil ini sejalan dengan harapan dan teori yang penulis bangun, sehingga $\mathrm{H}_{3}$ diterima. Hal ini membuktikan bahwa kenaikan struktur modal akan berdampak nyata pada kenaikan nilai perusahaan. Penelitian ini juga memberikan bukti bahwa leverage merupakan prediktor dalam meningkatkan nilai perusahaan.

Hasil penelitian ini sejalan dengan Teori MM dengan pajak (Modigliani \& Miller, 1963) yang menyatakan bahwa struktur modal dapat mempengaruhi nilai perusahaan dengan berubahnya tingkat hutang yaitu keuntungan dari pajak. Selanjutnya, hasil penelitian ini juga sejalan dengan Trade Off Theory yang menyatakan bahwa hutang dapat meningkatkan nilai perusahaan selama manfaat hutang lebih tinggi dari pada biaya kebangkrutan dan biaya keagenan perusahaan (Myres, 1984). Perusahaan dengan leverage yang tinggi menunjukkan bahwa perusahaan tersebut merupakan perusahaan yang berpotensi dan perusahaan yang besar sehingga menarik investor dan nilai perusahaan meningkat (Fitriani, 2016).

Hal penelitian ini juga didukung oleh hasil riset Darmawati et al. (2018) serta Muharti \& Anita (2017) yang menemukan bahwa leverage berpengaruh positif dan signifikan terhadap nilai perusahaan. Akan tetapi, hasil ini bertolak belakang dengan temuan Indrawan (2016), Anton (2016), serta Setiadi (2017) yang menemukan bahwa struktur modal berpengaruh negatif dan signifikan terhadap nilai perusahaan.

\section{Pengaruh Kebijakan Dividen terhadap Nilai Perusahaan}

Berdasarkan hasil analisis data yang telah dilakukan, ditemukan hasil bahwa kebijakan dividen berpengaruh positif dan signifikan terhadap nilai perusahaan manufaktur di BEI. Nilai koefisien yang positif dan tergolong signifikan secara statistik tersebut sesuai dengan harapan yang penulis bangun, sehingga $\mathrm{H}_{4}$ diterima. Ini menunjukkan bahwa ketika kebijakan dividen ditingkatkan, maka nilai perusahaan akan mengalami kenaikan secara signifikan.

Hasil ini sejalan dengan Bird in The Hand Theory yang menyakan abhwa investor lebih menyukai pemberian dividen yang tinggi dibandingkan dengan mengharapkan capital gain, dimana capital gain 
cenderung memiliki risiko yang lebih besar (Gordon \& Litner, 1956). Pemberikan dividen juga akan memancarkan sinyal ke investor sehingga nilai perusahaan meningkat (Darmawati et al., 2018). Ketika perusahaan memutuskan untuk membayar dividen, konflik agency antara pemegang saham mayoritas dan minoritas juga dapat diatasi, sehingga kinerja perusahaan akan meningkat (Villalonga \& Amit, 2006). Ini menunjukkan bahwa dividen memiliki pengaruh positif dan signifikan terhadap nilai perusahaan.

Hasil penelitian ini sejalan dengan riset yang pernah dilakukan oleh Kusumaningrum \& Rahardjo (2013), Pratama (2014), Anton (2016) serta Darmawati et al. (2018) yang menemukan bahwa kebijakan dividen berpengaruh positif dan signifikan terhadap nilai perusahaan. Akan tetapi, hasil riset ini bertentangan dengan riset Marheni (2018), Mayasari et al. (2015) serta Sari (2017) yang menemukan bahwa kebijakan dividen tidak berpengaruh signifikan terhadap nilai perusahaan.

\section{Kebijakan Dividen Memoderasi Pengaruh Profitabilitas terhadap Nilai Perusahaan}

Berdasarkan hasil analisis data yang telah dilakukan, ditemukan bahwa kebijakan dividen mampu memoderasi pengaruh profitabilitas terhadap nilai perusahaan manufaktur di BEI. Hal ini menunjukkan bahwa pengaruh profitabilitas terhadap nilai perusahaan tergantung pada tingkat pemberian dividen. Nilai koefisien yang diperoleh adalah positif yang menunjukkan bahwa kebijakan dividen memperkuat hubungan profitabilitas terhadap nilai perusahaan.

Hasil penelitian ini sejalan dengan Signalling Hypothesis yang menyatakan bahwa pemberian dividen dapat mengindikasikan perusahaan memiliki laba yang tinggi sehingga berdampak baik terhadap nilai perusahaan (Bhattacharya, 1979). Dalam jangka yang panjang, kebijakan dividen memberikan dampak positif terhadap kinerja akuntansi perusahaan (Darmawati et al., 2018). Dengan adanya pembayaran dividen tunai, penggunaan laba perusahaan akan dapat mengatasi permasalahan antara pihak pemegang saham mayoritas dengan pemegang saham minoritas sehingga pengaruh profitabilitas akan semakin meningkatkan nilai perusahaan (Puspaningtyas, 2017). Beberapa studi sebelumnya juga telah membuktikan bahwa kebijakan dividem mampu memoderasi pengaruh profitabilitas terhadap nilai perusahaan (Sundari \& Utami, 2013; Burhanuddin \& Nuraini, 2018).

\section{Kebijakan Dividen Memoderasi Pengaruh Likuiditas terhadap Nilai Perusahaan}

Hasil penelitian ini menunjukkan bahwa kebijakan dividen memberikan efek moderasi pada pengaruh likuiditas terhadap nilai perusahaan. Hal ini menunjukkan bahwa pengaruh likuiditas terhadap nilai perusahaan tergantung pada tingkat pemberian dividen. Nilai koefisien yang diperoleh yaitu positif, artinya kebijakan dividen menjadi faktor yang dapat memperkuat pengaruh likuiditas terhadap nilai perusahaan.

Hasil penelitian ini menunjukkan bahwa kebijakan dividen dapat meningkatkan kemampuan perusahaan dalam melunasi kewajiban jangka pendeknya, sehingga berdampak pada nilai pasar. Ketika perusahaan memutuskan untuk memberikan dividen, mana kinerja perusahaan akan meningkat 
dikarenakan meredamnya konflik agency yang ada (Schmid et al., 2010). Meningkatnya kinerja perusahaan akan membuat pasar merespon baik sehingga nilai pasar meningkat. Beberapa studi sebelumnya juga telah menemukan bahwa pengaruh likuiditas terhadap nilai perusahaan tergantung pada tingkat kebijakan dividen, yang memiliki arti bahwa kebijakan dividen mampu memperkuat hubungan profitabilitas terhadap nilai perusahaan (Siagian et al., 2013; Sirait \& Siregar, 2014)

\section{Kebijakan Dividen Memoderasi Pengaruh Leverage terhadap Nilai Perusahaan}

Berdasarkan hasil analisis data yang telah dilakukan, maka dapat disimpulkan bahwa kebijakan dividen dapat memoderasi pengaruh leverage terhadap nilai perusahaan manufaktur di BEI. Hal ini menunjukkan bahwa pengaruh leverage terhadap nilai perusahaan tergantung pada tingkat kebijakan dividen. Kemudian, nilai koefisien yang diperoleh adalah positif yang memiliki arti bahwa kebijakan dividen memperkuat pengaruh leverage terhadap nilai perusahaan.

Perusahaan yang memutuskan untuk memberikan dividen terkadang kekurangan dana untuk kebutuhan investasi, sehingga mendorong perusahaan untuk menggunakan dana eksternal (Burhanuddin \& Nuraini, 2018). Ketika penggunaan dana eksternal dalam berinvestasi pada proyek dengan NPV positif, maka nilai perusahaan akan meningkat (Jensen, 1986). Selain itu, ketika perusahaan membayar dividen, maka akan memberikan sinyal kepada debtholder sehingga pendanaan eksternal mudah diperoleh (Ross, 1977). Beberapa studi sebelumnya juga telah membuktikan bahwa kebijakan dividen mampu memoderasi pengaruh leverage terhadap nilai perusahaan (Khairani et al., 2018; Burhanuddin \& Nuraini, 2018).

\section{KESIMPULAN DAN SARAN}

\section{Kesimpulan}

Berdasarkan hasil analisis data yang telah dilakukan, maka dapat diambil kesimpulan bahwa:

1. Profitabilitas berpengaruh positif dan signifikan terhadap nilai perusahaan manufaktur di BEI.

2. Likuiditas berpengaruh positif tetapi tidak signifikan terhadap nilai perusahaan manufaktur di BEI.

3. Leverage berpengaruh positif dan signifikan terhadap nilai perusahaan manufaktur di BEI.

4. Kebijakan dividen berpengaruh positif dan signifikan terhadap nilai perusahaan manufaktur di BEI.

5. Kebijakan dividen mampu memoderasi pengaruh profitabilitas terhadap nilai perusahaan manufaktur di BEI.

6. Kebijakan dividen mampu memoderasi pengaruh likuiditas terhadap nilai perusahaan manufaktur di BEI.

7. Kebijakan dividen mampu memoderasi pengaruh leverage terhadap nilai perusahaan manufaktur di BEI.

\section{Saran}

Berdasarkan kesimpulan di atas, maka saran yang dapat penulis rekomendasikan adalah sebagai berikut : 
1. Disarankan pada pihak perusahaan manufaktur di BEI untuk dapat terus meningkatkan laba perusahaan, seperti dengan melakukan ekspansi usaha, berinvestasi pada proyek-proyek potensial, agar nilai pasar perusahaan terus meningkat.

2. Disarankan pada para investor di pasar modal indonesia untuk tidak mempertimbangkan rasio likuiditas perusahaan, karena hal tersebut tidak berdampak pada kinerja pasar perusahaan.

3. Disarankan pada pihak perusahaan manufaktur di BEI untuk berani menggunakan pendanaan eksternal untuk berinvestasi selama masih dalam batas yang wajar, karena hal tersebut berdampak positif terhadap nilai perusahaan.

4. Disarankan pada pihak perusahaan sektor manufaktur untuk terus memberikan dividen pada saat perusahaan memiliki laba, dikarenakan dividen dapat menjadi alat pemecah konflik agensi yang adal dalam perusahaan.

5. Disarankan pada peneliti lainnya untuk mengkaji faktor-faktor lain yang mempengaruhi nilai perusahaan, seperti kepemilikan saham, jumlah dewan komisaris, jumlah dewan direksi, keputusan investasi serta free cash flow untuk perkembangan di bidang corporate finance

\section{DAFTAR REFERENSI}

Abor, Joshua \& Godfred A. Bokpin. (2010). Investment Opportunities, Corporate Finance, and Dividend Payout Policy Evidence from Emerging Markets. Studies in Economics and Finance Vol. 27 No. 3.

Adelina, S., Restu Agusti \& Yesi Mutia Basri.

Apsari,Idha., Ayu Dwiatmanto dan Devi Farah Azizah. (2015). Pengaruh Return On Equity, Net Profit Margin, Debt To Equity Ratio dan Longterm Debt To Equity Ratio Terhadap Price Book Value.Jurnal Administrasi Bisnis (JAB). Vol 27. No 2.

Anita, Aprilia \& Arief Yulianto. (2016). Pengaruh Kepemilikan Manajerial dan Kebijakan Dividen Terhadap Nilai Perusahaan. Management Analysis Journal. Vol 5. No 1.

Anton, Sorin. (2016). The Impact of Dividend Policy on Firm Value. A Panel Data Analysis of Romanian Listed Firms.Journal of Public Administration, Finance and Law.1(1).

Astutik, D. (2017). Pengaruh Aktivitas Rasio Keuangan Terhadap Nilai Perusahaan (Studi Pada Industri Manufaktur). Jurnal STIE Semarang, 9(1), 35-53.

Baltagi, H. B. (2005). Econometric Analysis of Panel Data. John Wiley \& Sons Ltd.

Batten, J., \& Vo, X. V. (2019). Liquidity and firm value in an emerging market. The Singapore Economic Review, 64(02), 365-376.

Burhanudin \& Nuraini. (2018). Pengaruh Struktur Modal dan Profitabilitas terhadap Nilai Perusahaan dengan Kebijakan Dividen sebagai Variabel Pemoderasi. Eco-Entrepreneurship. Vol 3. No 2 .

Cahyono, Heri Setiyo. (2016). Keputusan Investasi, Keputusan Pendanaan dan Kebijakan Dividen Sebagai Determinan Nilai Perusahaan. Akuisisi. Vol 12. No 2.

Damodar N., Gujarati dan Dawn C. Porter. 2012. Dasar-dasarEkonometrikaBuku 2. Edisi 5.Raden Carlos Mangunsong (penj.). Jakarta: SalembaEmpat

Darmawati., Fauziah Mat N., WahyuddinAlbra., Muhammad Arifai dan Anshari Saleh. (2018). Dynamic Performance of Indonesian Public Company: An Analysis of Financial Decision Behavior. Cogent Economics \& Finance. 1 (6)

Donaldson, G. (1961). Corporate Debt Capacity: A Study of Corporate Debt Policy and The Determinants of Corporate Debt Capacity. Division of Research, Harvard Business School, Harvard University, Cambridge, MA

Fahmi, Irham. (2011). AnalisisLaporanAkuntansi. Bandung: ALFABETA. (2015). Analisis Laporan Keuangan, Cetakan Ke-5. Bandung : Alfabeta. 
(2006). Analisis investasi dalam Prespektif Ekonomi dan Politik. Bandung: PT. Refika Aditama.

Fang, V. W., Noe, T. H., \& Tice, S. (2009). Stock market liquidity and firm value. Journal of financial Economics, 94(1), 150-169.

Faure-Grimaud, A., \& Gromb, D. (2004). Public trading and private incentives. Review of financial Studies, 17(4), 985-1014.

Fauziah, Fenty (2017). Kesehatan Bank, Kebijakan Dividend An Nilai Perusahaan Teori Dan KajianEmpiris, RV Pustaka Horizon.

Harada, Kimie dan Pascal Nguyen. (2011). Ownership Concentration and Dividend Policy in Japan. Managerial Finance. Vol. 37. Iss. 4. pp. $362-379$.

Ghozali, Imam. (2011). Aplikasi Analisis Multivariate Dengan Program SPSS. Semarang: Badan Penerbit Universitas Diponegoro.

Gultom, M. C., dan F. Syarif. (2008). Pengaruh Kebijakan Leverage, Kebijakan Deviden, dan Earning Per Share Terhadap Nilai Perusahaan", Jurnal Akuntansi , 47.

Gordon dan Litner, John.(1962a). Distribution of Incomes of Corporations Among Dividends, Retained Earnings and Taxes. The American Economic Review. Vol 46, 97-113.

Halimah, I., \& Komariah. (2017). Determinasi Harga Saham pada Sektor Pertanian di BEI. Jurnal Unund. Vol 1. No 3.

Hanafi, Mamduh dan Abdul Halim. (2003). Analisis Laporan Keuangan. Edisi Revisi. Yogyakarta: UPP AMP YKPN.

Horne V. James dan John M Wachowicz. 2005. Prinsip-prinsip Manajemen Keuangan (Fundamental of Financial Management). Edisi 12. Diterjemahkan oleh Dewi Fitriasari. Jakarta: Salemba Empat.

Ihsan, Juli \& Sanjani. (2015). Efek Moderasi Profitabilitas pada Pengaruh keputusan pendanaan dan kebijakan dividen terhadap Nilai Perusahaan Jasa di Indonesia.Jurnal EMBA. Vol 1. No 3.

Ikatan Akuntan Indonesia (2017) Standar Akutansi Keuangan. Jakarta :Salemba Empat.

Indrawan. (2013) Pengaruh Investasidan Leverage terhadap Nilai Perusahaan Perusahaan Manfuaktur di BEIdenganProfitabilitassebagaiVariabel Moderator. Jurnal Akuntansi Keuangan. Vol 1. No 5 .

Jensen, M. C. (1986). Agency Costs Of Free Cash Flow, Corporate Finance, And Takeovers. The American Economic Review. 76 (2). 323-329.

Kasmir. (2014). Analisis Laporan Keuangan.Rajawali Pers, Jakarta.

Khidmat, W., \& Rehman, M. (2014). Impact of liquidity and solvency on profitability chemical sector of Pakistan. Economics management innovation, 6(3), 34-67.

Kurnia., I. (2017). Determinasi Nilai Perusahaan Manufaktur di Indonesia. Jurnal EMBA. Vol 2. No 1. Lubis, Ignatius Leonardus., Bonar M Sinaga \& Hendro Sasongko. (2017). Pengaruh profitabilitas, sruktur modal, dan likuiditas terhadap nilai perusahaan. Jurnal Aplikasi Bisnis dan Manajemen, Vol. 3 No. 3.

Le, Ben. (2019). Working Capital Management and Firm's Valuation, Profitability and Risk: Evidence From A Developing Market. International Journal of Managerial Finance.

Mentalita, H. (2019). The effect of liquidity, profitability, leverage and corporate social responsibility on company value with dividend policy as a moderating variable (empirical study in lq45 companies listed on the idx). International Journal of Public Budgeting, Accounting and Finance, 2(1), 1-13.

Modigliani, F. and Miller, M.H. (1958). The Cost of Capital, Corporate Finance, And The Theory of Investment. The American Economic Review. Vol. 48 No. 2.

Modigliani, F. and Miller, M.H. (1963). Corporate Income Taxes and The Cost of Capital: A Correction. The American Economic Review. Vol 53. No 2.

Muharti \& Anita.(2017). Pengaruh Keputusan Investasi, Pendanaan, Kebijakan Deviden Terhadap Nilai Perusahaan. Jurnal Ilmiah Ekonomi dan Bisnis. 13(2).

Munawir S. (2002). Analisis Laporan Keuangan. Yogyakarta: Liberty

Nam, H., \& Uchida, K. (2019). Accounts payable and firm value: International evidence. Journal of Banking \& Finance, 102, 116-137.

Natalia, Ami \& Retno Kusumastuti. (2017). An Analysis of Agency Costs and Dividend Payout Ratio of Non-Financial Companies. MIMBAR. Vol 33. No 2. 
Nikolaus, V. (2015, July 2). Determinants of Firm financial performance in Indonesia and the Netherlands: A comparison (5th IBA Bachelor Thesis Conference). Anjuran Enschede, The Netherlands

Nurlela, Rika dan Islahuddin.2008. Pengaruh Corporate Social Responsibility terhadap Nilai Perusahaan dengan Prosentase kepemilikan Menejerial sebagai Variabel Moderating.Simposium Nasional Akuntansi XI. Pontianak.

Patricia.,Primsa Bangun \& Malem Ukur Tarigan. (2018). Pengaruh Profitabilitas, Likuiditas, dan Ukuran Perusahaan Terhadap Nilai Perusahaan.Jurnal Manajemen Bisnis. 13(1).

Pascareno, B. E., \& Siringoringo, H. (2016). The effect of financial performance on company's value moderated by dividend policy.

Putri, Hanafiah PD dan Isynuwardhana. (2016). Pengaruh Keputusan Investasi, Keputusan Pendanaan Dan Kebijakan Dividen Terhadap Nilai Perusahaan (Studi Empiris Pada Sub Sektor Industri Barang Konsumsi Yang Terdaftar di Bursa Efek Indonesia Periode 2010-2013). Proceeding of Management : Vol.3, No.1 April 2016

Pratama, Sintoni Adi (2014). Pengaruh Keputusan Investasi, Keputusan Pendanaan dan Kebijakan Dividen terhadap Nilai Perusahaan. (Studi Kasus pada 50 Perusahaan dengan Kapitalisasi Pasar Terbesar di Bursa Efek Indonesia Periode 2010-2012. Program Magister Manajemen, Fakultas Ekonomi, Universitas Negeri Semarang, Indonesia.

Puspitaningtyas, Z. (2017). Efek Moderasi Kebijakan Dividen Dalam Pengaruh Profitabilitas Terhadap Nilai Perusahaan. JURNAL AKUNTANSI, EKONOMI dan MANAJEMEN BISNIS| e-ISSN: 2548-9836, 5(2), 173-180.

Ross, Stephen A. (1977). The Determination of Financial Structure: The Incentive-Signalling Approach. The Bell Journal of Economics. Vol. 8. No. 1.

Ruzita, Rahim, Mohd Yasimi Y., Norazlan and Fauziah Mat N. (2010). Investment, Board Governance and Firm Value: A Panel Data Analysis. International Review of Business Research Papers. Vol 6. No 5.

Roy, Amitava. (2015). Dividend Policy, Ownership Structure, And Corporate Governance: An Empirical Analysis of Indian Firm. Indian Journal of Corporate Governance.8(1).

Sari, Ratna Novita. (2017). Pengaruh Profitabilitas dan Kebijakan Dividen Terhadap Return Saham Perusahaan Manufaktur dengan Nilai Perusahaan Sebagai Variabel Intervening Periode 2010-2014. Jurnal Pendidikan dan Ekonomi, Volume 6, Nomor 1.

Sawir. Agnes. (2005). Analisis Kinerja Keuangan dan Perencanaan Keuangan. Jakarta: PT Gramedia Pustaka Utama.

Schmid, T, Ampenberger, M., Kaserer, C. \& Achleitner, A-K. (2010). Controlling shareholders and payout policy: Do founding families have a special "taste for dividends"?, CEFS Working Paper No. 2010-1. 2010.

Setiadi. (2017). Peranan Profitabilitas dalam Memoderasi Pengaruh Keputusan Keuangan terhadap NIlai Perusahaan Publik di Indonesia. Jurnal Ekonometrika. Vol 2. No 1.

Siagian, Ferdinand., Sylvia V. Siregar, \& Yan Rahadian. (2013). Corporate Governance, Reporting Quality, and Firm Value: Evidence From Indonesia. Journal of Accounting in Emerging Economies. Vol. 3 Issue 1. pp.4-20.

Sirait, Febriela dan Sylvia Veronica Siregar. (2014). Dividend Payment and Earnings Quality: Evidence from Indonesia. International Journal of Accounting and Information Management, Vol 22. Issue 2.

Sugiyono. (2016). Metode Penelitian Kuantitatif, Kualitatif dan R\&D. Bandung: PT Alfabet.

Sundari, Tri Wulan dan Wiwik Utami. (2013). Pengaruh Kinerja Keuangan Terhadap Nilai Perusahaan Dengan Kebijakan Dividen. Jurnal MIX, VoL 3. No 3

Sunariyah.(2014) Pengatar Pengetahuan Pasar Modal.Edisi kelima. Bandung : CV Alfabeta.

Wang, B. (2018). Ownership, institutions and firm value: Cross-provincial evidence from China. Research in International Business and Finance, 44, 547-565. 